\title{
DAYA TARIK EMOSIONAL DALAM IKLAN COCA COLA VERSI "RAYAKAN NAMAMU" SEBAGAI KAMPANYE ANTI-BULLYING
}

\author{
Edo Galasro Limbong, Rina Wahyu Winarni \\ Program Studi Desain Komunikasi Visual, Fakultas Bahasa dan Seni \\ Universitas Indraprasta PGRI \\ edogalasro_limbong@yahoo.com,rinawahyuwinarni66@hotmail.com
}

\begin{abstract}
Abstrak
Dalam membuat kreatif iklan diperlukan suatu daya tarik sehingga mudah untuk dipahami oleh khalayak yang menerima isi pesan tersebut. Salah satunya adalah menggunakan daya tarik emosional seperti yang digunakan Coca Cola dalam film iklannya. Hal ini yang menarik perhatian untuk mengetahui bagaimana konsep daya tarik emosional digunakan dan ditampilkan dalam iklan Coca Cola versi "Rayakan Namamu" sebagai kampanye antiverbal bullying. Film iklan yang hanya ditayangkan di internet ini bertujuan mengajak khalayak untuk berani melawan pemberian nama julukan/name calling. Penelitian ini menggunakan metode kualitatif dan menggunakan teori wacana yang dkembangkan oleh van Dijk dalam menganalisis data. Dalam hasil analisis penggunaan daya tarik yang digunakan Coca Cola adalah didapatkan pemilihan kata-kata untuk menjelaskan name calling yang telah dialami oleh tiga orang korban utama dan masyarakat umum. Selain itu, menampilkan ungkapan kesedihan dari orang tua ketiga korban utama dalam film iklan tersebut. Dengan demikian, salah satu manfaat dari penelitian ini adalah dapat mengetahui pengaplikasian daya tarik emosional dalam sebuah kreativitas iklan dan suatu gerakan kampanye.
\end{abstract}

Kata Kunci: Daya Tarik Emosional, Kreatif Iklan, Bullying

\begin{abstract}
In making creative advertising is required an attraction so easy to be understood by the audience who received the contents of the message. One is to use the emotional appeal that Coca Cola uses in its advertising film. It is of interest to know how the concept of emotional appeal is used and displayed in the Coca Cola commercial of "Celebrate Your Name" as an anti verbal bullying campaign. Advertising films that are only aired on the internet aims to invite the audience to dare to fight the naming / nickname. This research uses qualitative methods and uses discourse theory developed by van Dijk in analyzing data. In the analysis of the use of the attractiveness used by Coca Cola is the selection of words to explain the name calling experienced by the three main victims and the general public. In addition, it displays the expression of sadness from the parents of the three main victims in the film ad. Thus, one of the benefits of this research is to know the application of emotional appeal in an ad creativity and a campaign movement.
\end{abstract}

Key Words: Emotional Appeal, Creative Advertising, Bullying 


\section{PENDAHULUAN}

\section{Latar Belakang}

Pengembangan suatu pesan dalam iklan yang terdapat tahap-tahap dasar pemikiran penting untuk dilakukan. Hal ini biasa dikenal dengan istilah pengembangan kreatif iklan. Dengan demikian kreatif iklan merupakan menyusun suatu pesan menjadi ide-ide baru yang unik, wajar yang biasa digunakan sebagai suatu solusi komunikasi ataupun penemuan inti pesan (atau disebut penemuan "big idea")

Dalam kreativitas iklan diharapkan mampu menimbulkan daya tarik bagi konsumennya, maka selanjutnya dapat menuju pada tahap berikutnya yaitu mampu menciptakan kesadaran dan daya ingat konsumen terhadap produk, supaya konsumen berhasrat untuk beli produk tersebut. Pandangan ini menekankan bahwa suatu iklan harus menyajikan pesan penjualan yang paling persuasif dan kuat.

Daya tarik dasar yang sering digunakan dalam kreatif dunia periklanan terdiri atas (Morissan, 2014, hal. 343349):

1. Daya tarik rasio (rational appeal), yang berfungsi untuk mengkomunikasikan secara langsung informasi mengenai produk/layanan.

2. Daya tarik emosi (emotional appeal), yang berusaha mempengaruhi perasaan / emosi khalayak.

3. Daya tarik gabungan yaitu gabungan antar daya tarik rasio dan emosional.

Memahami penggunaan daya tarik iklan di atas, kecenderungan penggunaan daya tarik emosional (emotional appeal) banyak dilakukan pengiklan dalam usaha membentuk image, values dari produk yang ditawarkan.

Di awal tahun 2016 produk Coca

Cola mengeluarkan iklan versi "RayakanNamamu " yang tayang di internet dan tidak dipublikasi di stasiun televisi nasional maupun swasta. Menarik dari kreatif iklan Coca Cola dengan pendekatan daya tarik emosional tersebut adalah penemuan big idea dengan mengambil jenis film pendek dalam iklannya selain itu pesan dalam iklan tersebut mengarahkan kepada kampanye anti bullying khususnya dalam verbal bullying.

Coca-Cola Indonesia bersama komunitas anti-bullying, SudahDong, meluncurkan kampanye bertajuk Rayakan Namamu. Kampanye ini membawa misi untuk menyadarkan masyarakat Indonesia merayakan keindahan makna dari sebuah nama. Kampanye ditandai dengan peluncuran sebuah film pendek berisi cerita dari tiga orang yang mewakili korban bullying verbal melalui praktik pemberian nama julukan atau name calling. Kampanye yang menghadirkan berbagai inisiatif dengan cara unik dan menyenangkan (SindonewsDiandra Caesarlita: 13 Januari 2016. Diunduh 8 Oktober 2016)

Bullying secara verbal, yakni menyakiti orang lain dengan kata-kata, seperti memanggil dengan nama yang bukan namanya yang bersifat menghina, mengolok, menghina, mempermalukan atau mengancam. Menurut psikolog klinis, Liza Marielly Djaprie, efek verbal bullying memang tidak terlihat tapi cukup 'mematikan'. Efeknya bukan berbentuk mimisan ataupun wajah lebam seperti intimidasi fisik, tetapi menikam sekali ke dalamnya (jiwa). Oleh sebab itu biasanya tingkat bunuh diri paling banyak berasal dari cyber bullying dan verbal bullying. Perundungan dapat terjadi di mana saja, baik di sekolah, lingkungan sekitar bahkan rumah atau keluarga. (Warta Kesehatan: Moestavi; 14 Januari 2016. Diunduh 9 Oktober 2016), 
Dari data UNICEF terdapat $50 \%$ anak melaporkan mengalami bullying di sekolah. Hal ini seringkali mengakibatkan minat dan prestasi sekolah yang menurun, bolos sekolah, pindah atau bahkan drop-out dari sekolah. Name calling atau pemberian julukan kepada seseorang makin marak di kalangan masyarakat Indonesia yang sangat aktif dalam dunia maya. Ini bahkan terjadi sampai di kalangan anakanak. Sayangnya belum ada kesadaran yang kuat dari masyarakat untuk menanggulangi hal tersebut. (Sindonews.com-Caesarlita; 13 Januari 3016. Diunduh 8 Oktober 2016).

Tulisan ini menganalisis iklan Coca Cola versi \#Rayakan Namamu sebagai kampanye anti bullying melalui pendekatan analisis wacana dengan melihat pada teks dari iklan tersebut. Ketertarikan terhadap iklan ini dengan melihat pada 2.387.105 views sampai 15 Oktober 2016 dan 2.010 yang men like dengan komentar-komentar yang mengarah kepada keberhasilan iklan ini mengungkap fakta tentang name calling sebagai tindak bullying dan ajakan untuk memanggil nama dengan nama sebenarnya bukan nama julukan.

\section{Kajian Teori}

Emotional Appeals (Daya Tarik Emosional)

Emotional appeals (daya tarik emosional) merupakan salah satu pendekatan yang dapat digunakan dalam pembuatan iklan. Daya tarik emosional berusaha untuk memanfaatkan emosi positif (seperti humor, cinta, rasa bangga, rasa senang, dan sejenisnya) dan emosi negatif (seperti rasa takut, rasa bersalah, malu, tegang, sedih, waswas, dan seterusnya). Daya tarik emosional mendorong khalayak untuk menggunakan emosinya (Kertamukti, 2015, hal. 155).

Daya tarik emosional berhubungan dengan kebutuhan psikologis konsumen untuk membeli suatu produk. Banyak konsumen termotivasi untuk mengambil keputusan dan membeli suatu produk karena emosional dan perasaaan terhadap merek dapat menjadi lebih penting daripada pengetahuan terhadap atribut dan pernik-pernik produk tersebut. Sehingga menurut Suyanto (2004: 18) menyatakan, secara umum daya tarik emosional itu menyangkut kebahagiaan, keterkejutan, ketakutan, kesedihan, kemarahan dan kemuakan (http: // ejournal. uajy.ac.id /980/3/2EM15860. pdf).

Kreativitas Iklan

Membuat iklan merupakan pekerjaan profesional dari praktisi periklanan. Komunikasi periklanan memiliki tujuan yang jelas (Lund dalam Vestergaard dan Schroder, 1989: 49-70) seperti dikutip oleh Hamad (2007, hal. 120-121):

1. Menarik perhatian khalayak kepada iklannya itu sendiri,

2. Membangkitkan minat khalayak untuk mengetahui isi iklan,

3. Merangsang minat khalayak pada produk yang diiklankan,

4. Menciptakan keyakinan atas keunggulan produk,

5. Mendorong lahirnya tindakan untuk menggunakan produk.

Memahami tujuan komunikasi periklanan tersebut perlu dipertegas bahwa dalam usaha menarik atau merebut perhatian khalayak diperlukan perencanaan pesan dalam merancang kreatif iklan. Kreativitas perencanaan pesan juga bukan hanya berkenaan dengan isi (content), namun dalam hal pendekatan dan visualisasi pesan turut berperan.

Para kreator iklan tidak akan sembarang memakai bahasa, menyajikan fakta, dan menetapkan waktu dan media tempat pemblikasikan. Semuanya, akan dipertimbangkan dengan matang. Untuk pemakaian bahasa, (Hamad, hal. 121) 
pembuat iklan akan memilih kata dan gambar dengan secermat-cermatnya untuk digunakan pada: headline, tagline, slogan, body copy, ilustrasi, dan signature line.

Perumusan pesan iklan dapat memperhatikan isi visual, di mana pesan yang mengandung unsur visual cenderung lebih persuasif. Visualisasi di sini bisa berupa gambar, warna, karakter huruf dan lain yang dapat dilihat. Visualisasi sebuah produk mampu memberi pengaruh yang positif terhadap kepercayaan khalayak akan sebuah merek produk tersebut. Semakin besar dan semakin konkret gambar (visual) semakin positif tanggapan khalayak. (Hamad, 2007, hal. 4 \& 17)

\section{METODE PENELITIAN}

Metode penelitian yang digunakan adalah analisis isi kualitatif dengan pendekatan analisis wacana yang merupakan studi tentang struktur pesan dalam komunikasi. Analisis Wacana lebih menekankan kepada pemaknaan teks dengan dasar analisis interpretasi yang berpretensi menekankan pada pesan khusus, tanda dan elemen yang ada dalam obyek dapat ditafsirkan secara mendalam oleh peneliti. Dalam pendekatan ini pengandaian yang digunakan untuk memeriksa makna tersembunyi dapat dipelajari dan dibedah dan tidak berpretensi melakukan generalisasi. (Sobur, 2009, hal.70-72).

Penelitian ini menggunakan pendekatan analisis wacana Fairclough. Dalam Titscher, et al (2009, hal. 249) menyatakan pendekatan analisis wacana Fairlough dibagi dalam tiga hal, yaitu praktik sosiocultural, praktik wacana, dan teks. Ketiga hal tersebut dibuat dalam sebuah gambar sebagai berikut:

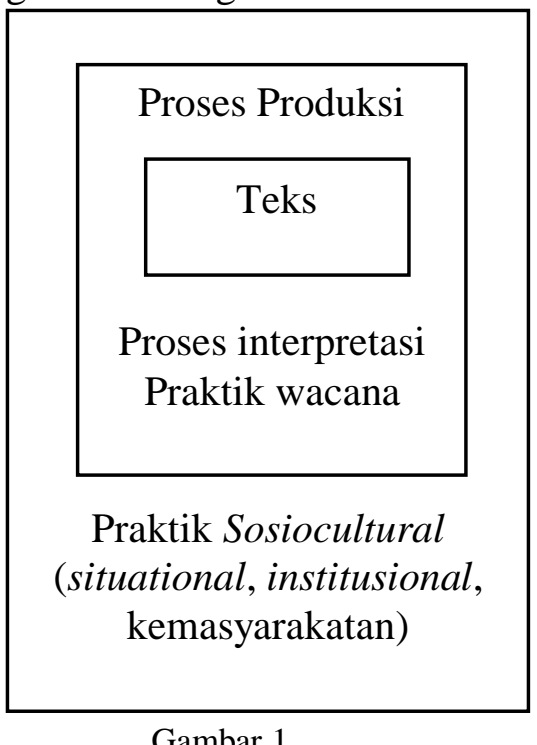

Analisis Wacana Fairlough Sumber: Titscher, et al (2000, hal. 249)

Dari ketiga unsur diatas hanya satu unsur yang akan diteliti dalam makalah ini, yaitu unsur teks. Dalam melakukan analisis teks tersebut peneliti membedahnya lebih dalam dengan menggunakan teori analisis wacana yang dikembangkan oleh Teun A. van Dijk (Sobur, 2009, hal. 70-72). Teori analisis wacana van Dijk memiliki berbagai elemen yang dapat diamati, yaitu: tematik (topik); skematik (skema); semantik (latar, detail, maksud, praanggapan, nominalisasi); sintaksis (bentuk kalimat, koherensi, kata ganti); stilistik (leksikon); dan retoris (grafis, metafora ekspresi).

Dalam melakukan analisis film iklan yang dibuat oleh Coca Cola dengan versi Rayakan Namamu menggunakan model Teun A.van Dijk dengan hanya melihat pada tiga struktur/elemen wacana sebagai berikut:

Tabel 1.

Struktur yang dianalisis

\begin{tabular}{ccc}
\hline Hal yang diamati & Elemen & \multicolumn{1}{c}{ Penjelasan } \\
\hline Tematik & Topik & $\begin{array}{l}\text { Topik merupakan informasi penting dari suatu } \\
\text { wacana dan memainkan peranan penting sebagai } \\
\text { pembentuk kesadaran sosial }\end{array}$ \\
\hline
\end{tabular}




\begin{tabular}{cll}
\hline Skematik & Skema & $\begin{array}{l}\text { Menggambarkan bentuk umum dari suatu teks, } \\
\text { strategi dari pembuat teks untuk mendukung topik } \\
\text { tertentu yang ingin disampaikan dengan } \\
\text { menyusun bagian-bagian dengan urutan-urutan } \\
\text { tertentu. }\end{array}$ \\
\hline Stilistik & Leksikon & $\begin{array}{l}\text { Pemilihan kata-kata atau frase menunjukan sikap } \\
\text { dan ideologi tertentu. }\end{array}$ \\
\hline
\end{tabular}

Ketiga elemen tersebut digunakan dalam analisis ini dikarenakan elemenelemen tersebut lebih dominan digunakan dalam film iklan yang dibuat oleh Coca Cola untuk mendukung penggunaan daya tarik emosional. Dengan demikian khalayak yang menyaksikan tayangan tersebut mudah untuk memahami maksud film iklannya yang sekaligus dapat menyentuh perasaan para khalayaknya.

\section{HASIL DAN PEMBAHASAN}

Berikut tujuh fakta yang melatar belakangi gerakan \#RayakanNamamu oleh Coca Cola dalam melawan verbal bullying ini (http://kawankumagz.com/Feature/News /7-Fakta-Di-Balik-Gerakan-

Rayakannamamu-Oleh-Coca-ColaDalam-Melawan-Verbal-Bullying):

Pertama, Name calling yaitu memanggil orang lain menggunakan nama julukan yang cenderung meledek, merendahkan, dan mengejek. Hal ini termasuk ke dalam kategori verbal bullying. Misalnya, memanggil seseorang dengan sebutan kribo, pendek, gendut, dan sebagainya. Hal ini dikarenakan berdasarkan data yang diperoleh oleh Coca Cola yaitu setiap tahunnya terdapat 3,5 juta koban bullying di Indonesia dan sebagian besarnya berasal dari name calling. Kedua ialah Tanda Akrab, Name calling umumnya berawal dari luculucuan dan sering dianggap sebagai tanda keakraban. Sehingga tanpa disadari panggilan itu seringkali menonjolkan kekurangan fisik seseorang, sehingga hal itu bisa membuat seseorang menjadi tidak percaya diri.

Hal yang ketiga adalah Menginspirasi. Berangkat dari fakta banyaknya kasus name calling ini, Coca Cola melakukan gerakan \#RayakanNamamu yang mengajak masyarakat untuk bangga dan meng-hargai nama sendiri. Keempat adalah Nama itu Doa. Pentingnya memanggil seseorang dengan nama yang sebenarnya sehingga kita harus bangga dengan nama kita. Nama itu juga mengingatkan bahwa kita dimiliki oleh seseorang, yaitu nama kita. Nama itu juga mengingatkan bahwa kita dimiliki oleh seseorang, yaitu keluarga.

Hal kelima yang melatar belakangi adalah nama itu Harapan. Sebuah nama itu harapan dari orang tua sehingga bangga dan menghargainya. Jika ada yang tidak menghargai nama itu berarti tidak usah menghargai orang tersebut. Faktor terakhir adalah Rayakan Namamu. Kemudian yang keenam adalah Rayakan Namamu. Dalam upaya mengangkat kampanye ini, Coca Cola membuat sebuah film pendek yang menceritakan pengalaman tiga orang yang pernah mengalami name calling. Di film tersebut menceritakan bahwa panggilan tersebut membuat ketiga orang (tokoh) merasa tidak pede, dan efeknya masih terasa sampai sekarang. Melalui kampanye yang dibuat dalam sebuah iklan, Coca Cola mengajak masyarakat untuk berhenti melakukan name calling, dan mulai memanggil teman dengan namanya aslinya.

Fakta terakhir yang melatarbelakangi adalah Bisa Ikut Berpartisipasi. 
Coca Cola mengajak khalayaknya bisa ikut berpartisipasi dalam kampanye \#RayakanNamamu ini. salah satu caranya dengan membuat avatar menggunakan Twibbon bertuliskan 'I Stand Against Name Calling' di akun media sosial masing-masing. Tulisan ini membuktikan bahwa kita turut serta dalam usaha menghentikan tindakan bullying. Twibbon ini bisa didapat di website CokeURL.com/RayakanNamamu.

Ketujuh fakta di atas yang melatarbelakangi dibuatnya film iklan tersebut, dari film iklan ini dilakukan analisis terhadap penggunaan daya tarik emosional berdasarkan tematik, skematik, dan stilistik. Pada tematik melihat topik utama Coca Cola dalam membuat film iklan dengan tema
Rayakan Namamu. Sementara untuk skematik menganalisis penggunaan daya tarik emosional berdasarkan alur cerita yang dibuat dalam film iklan tersebut mulai dari awal sampai akhir pada film iklan tersebut. Sedangkan analisis stilistik adalah untuk melihat pemilihan name calling yang digunakan guna lebih menekankan daya tarik emosional dalam film iklan tersebut. Secara lebih jelas, penjabaran ketiga elemen tersebut dapat dilihat sebagai berikut:

Analisis Wacana van Dijk

Berikut ini dijabarkan hasil dan diskusi dari penelitian yang menggunakan analisis wacana van Dijk untuk melihat penggusebagai berikut:

1. Tematik

\begin{tabular}{|c|c|c|}
\hline Scene & Elemen & Daya Tarik Emosional \\
\hline 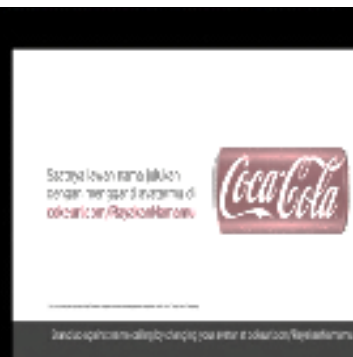 & $\begin{array}{l}\text { Topik utama: } \\
\text { Teks: } \\
\text { Saatnya lawan nama } \\
\text { julukanmu dengan } \\
\text { mengganti avatarmu di } \\
\text { Cokeurl. } \\
\text { RayakanNamamu. com/ }\end{array}$ & $\begin{array}{l}\text { Tematik atau topik menggugah } \\
\text { emosi audiens untuk berani } \\
\text { melawan nama julukan dan } \\
\text { memberi kesan bahwa sudah } \\
\text { saatnya penonton untuk melawan } \\
\text { verbal bullying. }\end{array}$ \\
\hline
\end{tabular}

2. Skematik

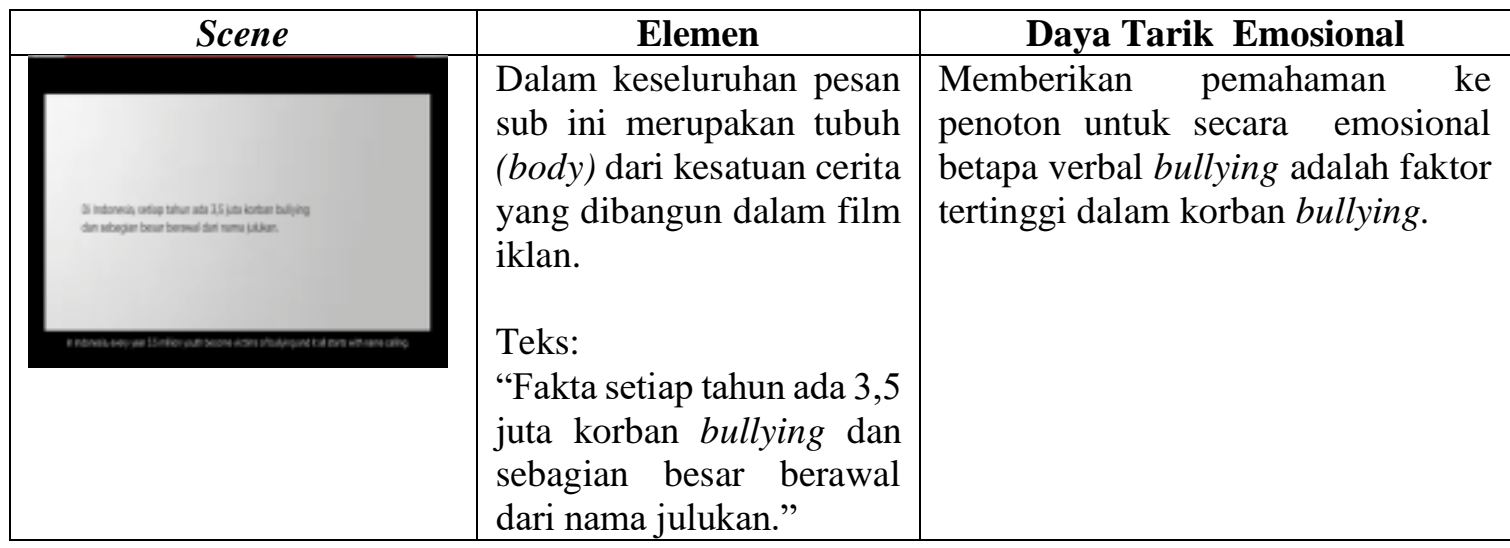




\begin{tabular}{|c|c|c|}
\hline & $\begin{array}{l}\text { Teks: } \\
\text { "Ada yang manggil Raiso } \\
\text { ada yang manggil macam- } \\
\text { macam deh pokoknya." } \\
\text { "Raiso itu kan artinya } \\
\text { kalau dalam bahasa Jawa } \\
\text { nggak bisa apa-apa. } \\
\text { Pokoknya beli kosmetik } \\
\text { sebanyak mungkin biar } \\
\text { gw tampak, biar sesuai } \\
\text { dengan nama gw gitu loh. } \\
\text { Biar sesuai dengan Raiza } \\
\text { Andini yang cantik banget } \\
\text { itu namanya." }\end{array}$ & $\begin{array}{l}\text { Menampilkan testimoni tiga orang } \\
\text { korban yang mengalami bullying } \\
\text { nama julukan /name calling } \\
\text { Episode atau kisah utama dari cerita } \\
\text { disajikan dengan memberi latar } \\
\text { pendukung fakta dari "tokoh" } \\
\text { korban verbal bullying. } \\
\text { Pesan emosional yang dibangun } \\
\text { untuk memberikan pemahaman ke } \\
\text { penonton agar ikut merasakan } \\
\text { pemaparan dari ketiga "tokoh" } \\
\text { korban verbal bullying. } \\
\text { Emosional yang dibangun dengan } \\
\text { memaparkan kesedihan korban } \\
\text { ketika diberi julukan "kribo" yang } \\
\text { akhirnya menjadi "bokri". } \\
\text { Testimoni korban berikutnya yang } \\
\text { dengan mimik sedih menyampaikan } \\
\text { ketidakihlasanya dijulukin "raiso" } \\
\text { yaitu orang yang tidak bisa apa-apa. } \\
\text { Berikutnya korban verbal bullying } \\
\text { yang dari kecil diberi julukan gigi } \\
\text { kuning yang akhirnya mendapat } \\
\text { julukan "gigi". Korban di sini pria } \\
\text { yang tidak terlalu sedih } \\
\text { menyampaikan ceritanya. }\end{array}$ \\
\hline "Gig" & $\begin{array}{l}\text { Teks: } \\
\text { "Mungkin dipanggil gigi } \\
\text { kuning gigi kuning terus } \\
\text { cape juga kali panggil } \\
\text { nama panjang jadi gigi } \\
\text { gigi gigi sampai sekarang. } \\
\text { "Sebel juga tapi gigi gw } \\
\text { nggak bisa kembali juga. } \\
\text { Pasti gw langsung down. } \\
\text { Ya jadi nggak pede sih." }\end{array}$ & \\
\hline benchest & $\begin{array}{l}\text { Memberikan fakta bahwa } \\
\text { name calling sudah } \\
\text { dimulai sejak kecil dan } \\
\text { terbawa sampai dewasa. } \\
\text { Teks: } \\
\text { "Sebagian mendapatkan } \\
\text { nama julukan sejak kecil } \\
\text { dan terbiasa hidup dengan } \\
\text { itu." } \\
\text { "Seharusnya Tidak" }\end{array}$ & $\begin{array}{l}\text { Membentuk secara emosional } \\
\text { pengetahuan ke penonton tentang } \\
\text { bahaya name calling. }\end{array}$ \\
\hline
\end{tabular}




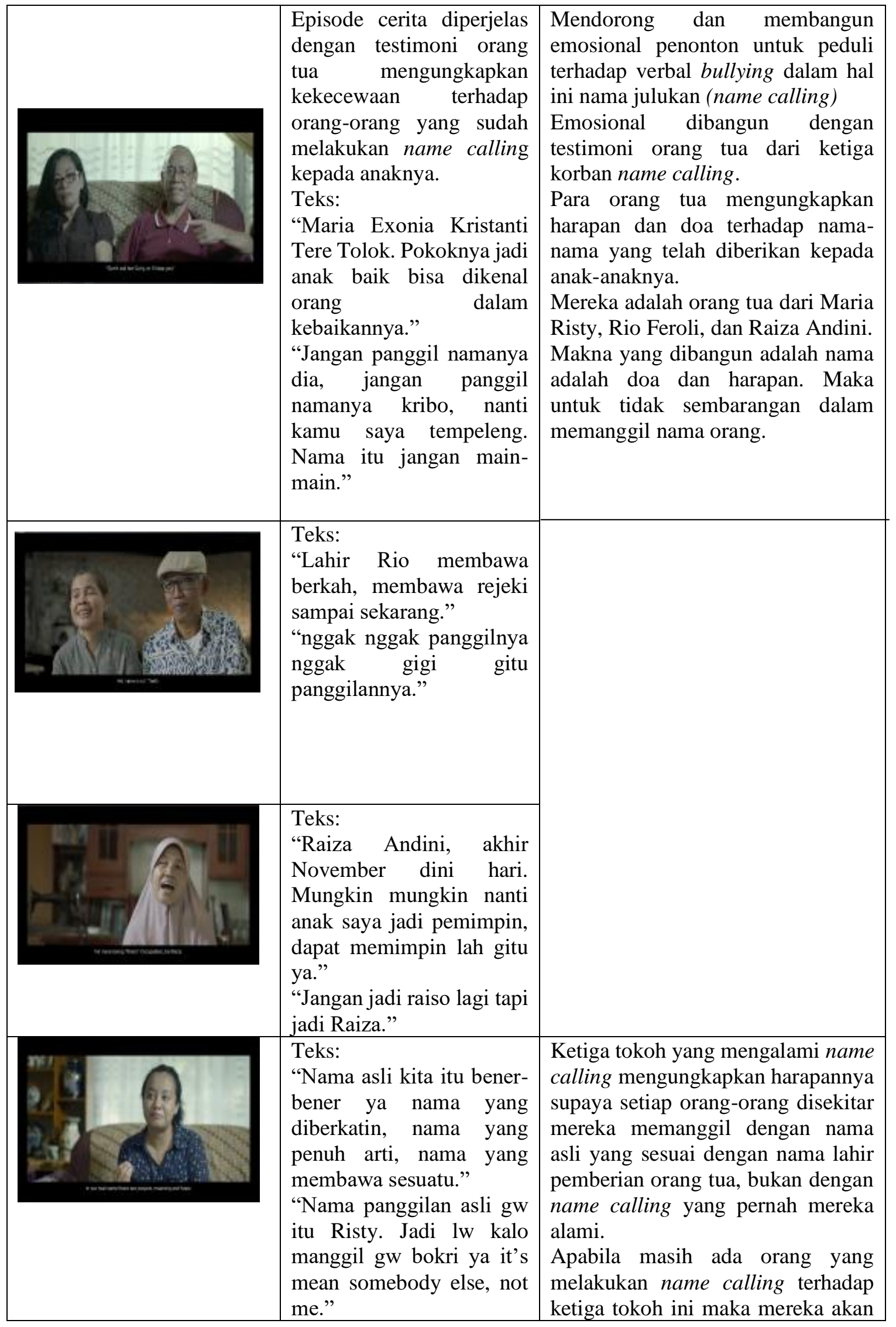




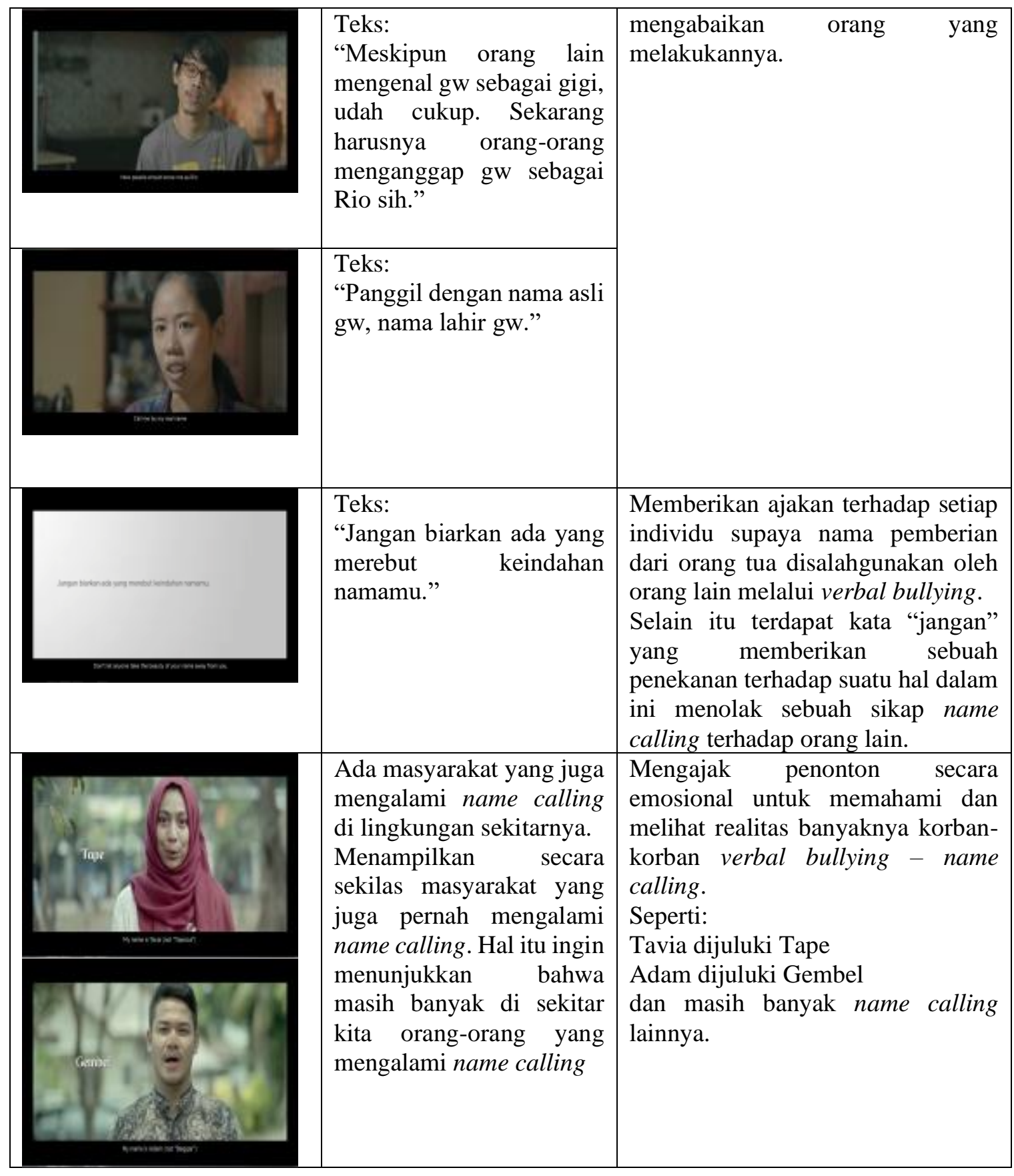

3. Stilistik

\begin{tabular}{|l|l|l|}
\hline Scene & \multicolumn{1}{|c|}{ Elemen } & \multicolumn{1}{c|}{$\begin{array}{l}\text { Daya Tarik Emosional } \\
\text { Tiga tokoh yang mewakili } \\
\text { pemilihan name calling sebagai } \\
\text { korban verbal bullying "Kribo" } \\
\text { dan "Gigi" merupakan pemilihan }\end{array}$} \\
\hline Skema & $\begin{array}{l}\text { Teks: } \\
\text { "Gw ingat banget ada } \\
\text { temen perempuan manggil } \\
\text { kribo, kribo. Jadi dia } \\
\text { kayak mengulang kata } \\
\text { kribo. Akhirnya kribo }\end{array}$ & $\begin{array}{l}\text { inilah yang sering muncul dalam } \\
\text { pergaulan sehari-hari sebagai } \\
\text { kekurangan fisik yang menonjol. }\end{array}$ \\
\hline
\end{tabular}




\begin{tabular}{|c|c|c|}
\hline & $\begin{array}{l}\text { kribo kribokri akhirnya } \\
\text { bokri." }\end{array}$ & $\begin{array}{l}\text { "Kribo" identik dengan rambut } \\
\text { yang ikal keriting tidak beraturan. }\end{array}$ \\
\hline & $\begin{array}{l}\text { Teks: } \\
\text { "Ada yang manggil Raiso } \\
\text { ada yang manggil macam- } \\
\text { macam deh pokoknya." } \\
\text { "Raiso itu kan artinya } \\
\text { kalau dalam bahasa Jawa } \\
\text { nggak bisa apa-apa. }\end{array}$ & $\begin{array}{l}\text { "Gigi" bentuk dari fisik susunan } \\
\text { gigi yang melebihi garis bibir } \\
\text { (tonggos). Serta warna gigi } \\
\text { kuning yang dianggap tidak bersih. } \\
\text { Pemilihan nama Raisa yang diberi } \\
\text { julukan "Raiso" dalam bahasa } \\
\text { Jawa mempunyai arti orang yang }\end{array}$ \\
\hline "Gigi" & $\begin{array}{l}\text { Teks: } \\
\text { "Mungkin dipanggil gigi } \\
\text { kuning gigi kuning terus } \\
\text { cape juga kali panggil } \\
\text { nama panjang jadi gigi } \\
\text { gigi gigi sampai sekarang. } \\
\text { "Sebel juga tapi gigi gw } \\
\text { nggak bisa kembali juga. } \\
\text { Pasti gw langsung down. } \\
\text { Ya jadi nggak pede sih." }\end{array}$ & $\begin{array}{l}\text { Ke tiga name calling tersebut } \\
\text { mengandung daya tarik emosional. } \\
\text { Kekuatan stilistik dengan } \\
\text { penggunaan daya tarik emosional } \\
\text { menjadi tujuan kreatif iklan ini } \\
\text { agar khalayak dapat merasakan } \\
\text { emosi tiga tokoh sebagai korban } \\
\text { verbal bullying (name calling). }\end{array}$ \\
\hline
\end{tabular}

*Sumber gambar: Youtube

\section{SIMPULAN}

Penelitian ini menunjukkan bahwa sebuah kegiatan kampanye sosial dapat dilakukan dengan menggunakan daya tarik emosional (emotional appeal) dalam mendukung tematik iklan yang dibuat. Keunggulan daya tarik emosional dalam tematik iklan Coca Cola versi Rayakan Namamu dapat menggugah emosi perasaan audiens dengan mendekatkan pada fakta-fakta di balik sebuah nama, hal lain tematik iklan ini dapat memberikan image yang positif bagi produk Coca Cola yang dirasa langsung mempunyai kepedulian terhadap masalah sosial yang ada di Indonesia yaitu verbal bullying.

Dalam mengaplikasikan daya tarik emosional, film iklan Coca Cola menekankan fear appeal di mana kekuatan daya tarik ini dapat menggugah rasa kekhawatiran audiens terhadap dampak dari verbal bullying khususnya name calling. Pemilihahan tiga korban name calling yang memberikan testimoni merupakan pemilihan yang tepat, karena julukan-julukan itulah yang sering muncul dalam pergaulan sehari-hari. Maka menggunakan daya tarik emosional dalam sebuah iklan kampanye dianggap efektif karena lebih mendekatkan isi pesan terhadap sisi psikolgis khalayak yang melihat atau menyaksikan iklan tersebut.

Penggunaan bahasa dalam kreativitas iklan Coca Cola versi Rayakan Namamu, terlihat sangat memperhatikan khalayak yang dituju yaitu remaja. Hal ini terpapar dari bahasa verbal dan non verbal yang digunakan mengarah kepada bahasa remaja saat ini. Usaha ini dilakukan sebagai cara menarik atau merebut perhatian khalayak sasaran, karena remaja rentan sekali dengan tindakan verbal bullying khususnya name calling.

Hal menarik lain yang perlu diungkap adalah peluncuran film iklan Coca Cola versi Rayakan Namamu ini dibarengi dengan peluncuran kemasan Coca Cola edisi nama-nama popular 
orang Indonesia yang ditayangkan di televisi. Contoh kemasan:

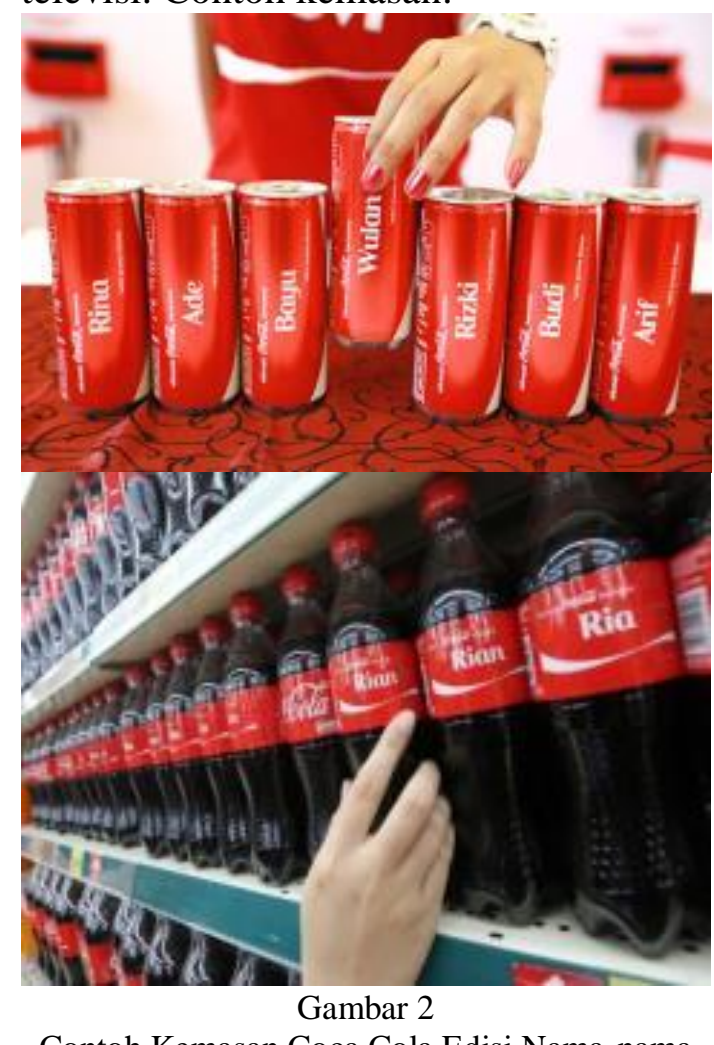

Contoh Kemasan Coca Cola Edisi Nama-nama

Hal ini merupakan salah satu strategi pasar yang saling bersinergi antara iklan dengan kemasan produk.

\section{DAFTAR PUSTAKA}

Sumber buku:

Hamad, I. (2007). Perencanaan Program Komunikasi. Jakarta: Universitas Terbuka.

Kertamukti, R., (2015). Strategi Kreatif dalam Periklanan. Jakarta: PT Raja Grafindo Persada.

Morissan, M. A., (2014). Cetakan ke-3. Periklanan: Komunikasi

Pemasaran Terpadu. Jakarta: Kharisma Putra Utama.
Sobur, A., (2009). ANALISIS TEKS MEDIA Suatu Pengantar untuk Analisis Wacana, Analisis Semiotik, dan Analisis Framing. Bandung: PT Remaja Rosdakarya.

Tim Penulis. (2006). Webster's English Thesaurus. Batam: Karisma Publishing Group.

Sumber internet:

http://dimaspratama20.blogspot.co.id/20 13/11/menentukan-daya-tarikiklan-di-ambil.html

http://e-

journal.uajy.ac.id/980/3/2EM158 60.pdf

http://kawankumagz.com/Love-AndLife/Life/Apa-Sih-Bullying-Itu

http://www.academia.edu/8307317/Defi nisi_Bullying_Apakah_arti_kata _bullying

https://www.stopbullying.gov/what-isbullying/definition/index.html

Warta Kesehatan: Moestavi; 14 Januari 2016. Diunduh 9 Oktober 2016

Sindonews.com-Caesarlita; 13 Januari 3016. Diunduh 8 Oktober 2016

https://www.youtube.com/watch?v=Hkb oBCpm83g

http://kawankumagz.com/Feature/News/ 7-Fakta-Di-Balik-GerakanRayakannamamu-Oleh-CocaCola-Dalam-Melawan-VerbalBullying. Diunduh 22 November 2016 